\title{
Halk Eğitim Merkezi Denetim Rehberinin Yasal Belgeler ve Alanyazın Temelinde Incelenmesi
}

\author{
Doç. Dr. Nedim Özdemir \\ Ege Üniversitesi -Türkiye \\ nedim.ozdemir@ege.edu.tr
}

\author{
Aylin Özkanlı \\ Izmir il Milli Eğitim Müdürlüğü-Türkiye \\ aylinozkanli@gmail.com
}

\begin{abstract}
Özet:
Bu çalışmanın amacı, Milli Eğitim Bakanlığı Teftiş Kurulu Başkanlığı tarafından Halk Eğitim Merkezleri için hazırlanan denetim rehberinin temel bölümlerinin yasal belgeler ve denetim alanyazını açısından incelenmesidir. Bu çalışmada nitel araştırma yaklaşımı benimsenmiş olup doküman incelemesi tekniği kullanılmıştır. Araştırma kapsamında Halk Eğitim Merkezleri için hazırlanan denetim rehberi incelenmiştir. Bu kapsamda söz konusu belgenin denetim alanyazını ve yasal belgeler ile karşılaştırılması için internet ortamında son on yılda Halk Eğitimi Merkezlerinde Denetimi konu edinen tezler, makaleler ve rehberin içerisinde geçen yasal belgeler kullanılmıştır. Elde edilen veriler içerik analizi kullanılarak çözümlenmiş, yasal belgeler ve alanyazın olmak üzere iki tema altında sunulmuştur. Araştırmada, rehberin yayın tarihinden sonra yayınlanan Hayat Boyu Öğrenme Kurumları Yönetmeliği nedeniyle yasal belgelere göre ana belge temelli tutarsızlıkların fazla olduğu bulunmuştur. Yasal belgelere göre tutarlı olan kısımları Halk Eğitimi Merkezleri ile dolaylı yoldan ilişkili olan hukuki dayanaklar olduğu tespit edilmiştir. Alanyazına bakıldığında yayınlanan denetim rehberinin genel olarak tutarlı olduğu ve eğitim denetimine ilişkin bilgilerin yer aldığı saptanmıştır. Bu tutarlılığa rağmen denetim rehberinde alanyazın ile farklılık gösteren ifadelerde görülmüş "iç̧erik eksikliği", "Alan yazına Atıfsızlık", "Kavram tutarsızlığı" ve "Aykırılık" olmak üzere dört kod ile eksiklikler tespit edilmiştir. Bulgular yasal dayanaklar ve alanyazın ile desteklenerek yorumlanmıştır.
\end{abstract}

Keywords: Denetim, Denetim Rehberi, Halk Eğitim Merkezi

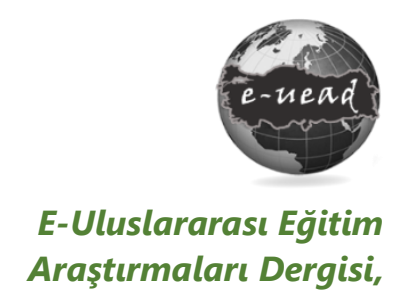

Cilt: 12, Sayt: 1, 2021, ss. 124-140

DOI: 10.19160/ijer.867017

Gönderim : 02.08.2020 Kabul : 28.03.2021

\section{Önerilen Atıf}

Özdemir, N., Özkanlı, A. ve Altuntaş, F. (2021). Halk Eğitim Merkezi Denetim Rehberinin Yasal Belgeler ve Alanyazın Temelinde İncelenmesi, E-Uluslararası Eğitim Araştırmaları Dergisi, Cilt: 12, Sayı: 1, 2021, ss. $124-140$, DOI: $10.19160 /$ ijer.867017 


\section{GiRiş}

Denetim, örgütün hedeflerine ulaşıp ulaşmadığını belirlemek, hedeflerin sonuçlarının etkisini görmek ve örgüt üyelerinin bu süreçteki ilerleyişini anlamakta önemli bir rol oynamaktadır. Eğitim denetimi ise eğitim örgütlerinin amaçlarının gerçekleşme düzeyini belirlemek ve daha nitelikli sonuçlar için tedbirler almayı öngörür (Toprakçı ve Akçay, 2016). Buna göre denetim, bir yönü ile paydaşların vizyon oluşturmaya katıldığı bir süreç olarak değerlendirilebilir (Glickman, Gordon ve Ross-Gordon, 2014). Denetlenmeyen işlerin, önce kendi içinde amacından uzaklaşması, daha sonra ise eğitim kurumunun temel hedeflerine ulaşmasında güçlükler çıkarması muhtemeldir. Eğitim hizmetlerinin yürütülmesinde karşılaşılan sorunlar ve temel aksaklıklar denetim ile ortaya çıkabilmektedir. Bu aksaklıkların ve temel problemlerin çözülmesi için hangi tür tedbirler alınacağı denetlemenin sonucuna göre belirlenmektedir (Altunay, 2016). Eğitim sisteminde önemli bir yere sahip olan denetim, eğitsel aktiviteleri etkili ve verimli devam ettirmek için gerekli olan önemli bir süreçtir (Özdemir, 2020). Eğitimin öneminin vurgulandığı her durumda denetim olmazsa, eğitim desteksiz kalır. Çünkü denetim eğitimcilere bir rehber gibidir (Altınışık ve Binbir, 2015). Denetim süreçlerinin etkili biçimde uygulanması, eğitim yapısının düzenlenmesi ve iyileştirilmesi bakımından büyük önem taşımaktadır (Beytekin ve Tas, 2017). Eğitimde yapılan işlemlerin, var olan hukuki duruma, belirlenen amaca, mevcut plana ve eldeki imkânlara (madde ve insan kaynaklarına) uyup uymadığını kontrol etme süreci eğitim denetimidir (Toprakçı, Çakırer, Bilbay, Bagcivan ve Bayraktutan, 2010).

Halk eğitim, yetişkin eğitimi ya da hayat boyu öğrenme kavramları yaygın eğitim araştırmalarında kullanılan kavramlardır. Hayat boyu eğitim, örgün eğitimi hali hazırda almakta olan çocukların tamamlayıcı eğitsel faaliyetlerini kapsayabilir. Öte yandan, yetişkin eğitimi ve halk eğitim daha çok örgün eğitimi alamamış, yarım bırakmış veya bitirmiş bireyleri kapsadığı görülmektedir. Yaygın öğrenme, örgün ve yaşayarak öğrenme özelliklerini birlikte taşır. Yaşayarak öğrenmede kasıt ve amaç yokken, yaygın öğrenme amaçlı ve yapılandırılmıştır (Werquin, 2010). Bir yaygın eğitim kurumu olan Halk Eğitim Merkezlerinin denetimine ilişkin yapılan araştırmalar, denetimlerde yaşanan sorunları (Sabancı ve Rodoplu, 2013) ve denetim süreçlerinin etkililiğinin önemini (Güneş,1985) ön plana çıkarmaktadır. Sabancı ve Rodoplu (2013) çalışmasında, Antalya ilinde altı Halk Eğitim Merkezi müdürü ile yürütmüş olduğu çalışmada, denetim sürecinde karşılaşılan en önemli sorunun çalışanların denetiminde yaşandığını raporlamıştır. Buna göre, çalışanların yürüttüğü işlerin kontrol odaklı ve şekil yönünden denetlenmesinin onlarda rahatsızlık oluşturduğu vurgulanmıştır. Güneş (1985) çalışmasında ise, araştırmaya katılan bakanlık denetçilerinin yarısına yakınının Halk Eğitim Merkezlerinin üç yıldan daha fazla süredir denetlenmediğini belirtmiştir. Ayrıca denetimlerin çoğunlukla maddi durum, büro işleri ve araç-gereç gibi konularda gerçekleştiğini; buna karşın eğitim ve öğretim işlerinin niteliğinin denetlenmediğini dile getirmiş̧ir. Duman (1991), halk eğitimi alanında Bakanlık denetçilerinin ve uzmanlarının yetişmişlik seviyelerinin yetersiz olduğunu savunmaktadır. Yukarıda sıralanan çalışmalar denetçilerin farklı alanlara odaklandığını ve bu doğrultuda denetimde uyum birliğinin sağlanamadığını göstermektedir. Bu nedenle kurumsal hedefler ile çalışanların eylemleri arasındaki uyumun belirlenmesi güçleşmektedir. Bu sornunu azaltmak üzere Milli Eğitim Bakanlığı 2016 yılında faklı kurumların özelliklerine göre hazırlanmış 16 adet denetim rehberi yayımlamıştır. Söz konusu rehberler ile kurumların denetiminde hangi ölçütlerin göz önüne alınacağı belirlenmiştir. Bu araştırma ile Halk Eğitim Merkezleri için hazırlanan "Rehberlik ve Denetim Rehberinin" yasal belgeler ve alanyazın ile ne ölçüde uyum gösterdiğini incelemek ve devamında yapılacak araştırmalara, işleyişe yardımcı olmak istenmektedir. Halk eğitimi merkezleri rehberlik ve denetim rehberinde yasal belgeler ve alanyazın temelinde tutarsızlıkların belirlenmesi, uygulayıcılar ile araştırmacılara yönelik öneriler geliştirilmesi araştırmanın temel amacını oluşturmaktadır. İncelenen denetim rehberi ile sorunların saptanması, denetim sürecinde standartların oluşmasına katkıda bulunacağı ve elde edilen bulgular ile denetim rehberinin güncellenmesinde bir kaynak olarak kullanılabileceği düşünülmektedir. 


\section{Yetişkin Eğitimi}

Çağdaş toplumlar formal eğitime ağılık verip informal eğitimi geri planda tutmayı istediğinden yaygın eğitime önem vermeye çalışır. Yaygın eğitim, örgün eğitimin yanında ya da dışında formal eğitimi de kapsar. Türkiye'de Milli Eğitim Bakanlığı formal eğitimin örgün ve yaygın eğitim basamaklarının ikisinden de sorumludur (Toprakçı ve Arslan,2016). Formal eğitim faaliyetleri devletin yönetimi ve denetimi altında iken informal eğitim faaliyetleri hayatın içinde kendiliğinden oluşur ya da belirli kişi ve kuruluşlar tarafından verilir (Toprakçı ve Akçay, 2016). Yetişkin eğitimi, yaşam boyu öğrenme kapsamında örgün eğitime devam eden ya da örgün eğitimi tamamlamış bireylerin yeteneklerini ve bilgilerini geliştirme amacıyla katıldıkları öğrenme etkinlikleri olarak tanımlanmaktadır (MEB, 2018). Okçabol'a (2006) göre, yetişkin eğitimi, sorunlara çözüm getirmeyi amaçlayan faaliyetlerdir. Yetişkinler, bilgi seviyelerini artırmak, maddi durumlarını iyileştirmek, boş vakitlerini değerlendirmek, mesleki gelişimlerini artırmak, yeni insanlarla taşımak ve/veya iş hayatında uzmanlaşmak gibi birçok nedenden dolayı bu etkinliklere katılım göstermektedir (Fidan, 1986). Yaşam boyu öğrenme mekân, zaman, yaş, maddi durum, eğitim seviyesi gibi ifadelerdeki kısıtlamaları kaldırmakta ve herkese fırsat eşitliği sunmaktadır (Dinevski ve Dinevski, 2004). Dünya Yetişkin Eğitimi Derneği'nin 1919 yılında yayınladığı raporda yetişkinlerin eğitim ve öğretimininim yaşam boyu devam etmesinin önemi vurgulanmıştır (Grace, 2000).

Bu kavram ilk olarak askeri alanda çalışan yetişkinlerin eğitim ihtiyaçlarını gidermek üzere gündeme gelmiştir (Field, 2001). Yetişkin eğitimi alanında faaliyet gösteren UNESCO ise yetişkin eğitiminde ilk toplantısını 1949 senesinde gerçekleştirmiştir. Daha sonrasında UNESCO'nun eğitim faaliyetlerine üniversiteler ve sendikalar başta olmak üzere başka kuruluşlar da katılmaya başlamıştır (Yayla, 2009). Türkiye'de Cumhuriyet sonrası dönemde yetişkin eğitimi üzerinde yoğun bir şekilde durulmaya başlanmıştır. Millet Mekteplerinin açılmasıyla birlikte 16-40 yaş arasındaki bütün vatandaşlara okuma yazma öğretilmeye başlanmıştır. 1928 yılında başlayan Millet Mektebi uygulaması 1932 yılında Halk Evlerine dönüşmüş ve 1951 yılına kadar spor faaliyetleri, mesleki, kültürel ve boş vakit değerlendirme gibi etkinliklerini sürdürmüştür (Özacun, 2001). İlerleyen yıllarda tarım alanında çalışan yetişkinlerin eğitimi için Halk Eğitim Büroları açılmış; köy ve kasabalarda halka ait okuma odaları oluşturulmuştur. Halk Eğitim Merkezlerinin yaygınlaşmaya başladığı dönem ise 1956 yılı olarak gösterilebilir (Özacun, 2001). Bu merkezler, 1960 yılından itibaren Milli Eğitim Bakanlığı bünyesinde çalışmalarına devam etmiştir.

OECD üyesi ülkeler içerisinde yetişkin eğitimine katılım oranı ortalama \%44 olarak gerçekleşmekle birlikte en yüksek oran \%68 ile İsviçre'de yaşanmıştır. Türkiye ise \%18 ile OECD ortalamasının altından kalmıştır (OECD, 2019). Türkiye'de yetişkin eğitimini gerçekleştiren kurumlar, (i) Halk Eğitimi Merkezleri, (ii) Olgunlaşma Enstitüleri ve (iii) Açık Öğretim okullarıdır (MEB, 2018). Halk eğitimi merkezleri Hayat Boyu Öğrenme kapsamında kurslar ile eğitici faaliyetlerin düzenlendiği kurumlardır. Halk Eğitimi Merkezlerinde düzenlenen kurslar ile yetişkinler hem kendilerini geliştirmekte hem de sertifika ya da belge alabilmektedir (MEB, 2018). Yetişkin eğitimine yönelik çalışmalar incelendiğinde sağlıklı yaşam, hayattan zevk alma, emeklilik döneminde bilgi edinme, farklı yaş gruplarıyla dayanışma ve sosyal sorumluluk (Canatan ve Boz, 2019) gibi olumlu etkilerinin olduğu görülmektedir. Buna karşın yaşam boyu eğitim ile yaşam doyumları arasında zayıf bir ilişkinin olduğu saptanmıştır (Akyol, Başaran ve Yeşilbaş, 2018). Türkiye'de yaygın eğitimin niteliği konusunda yapılan tartışmalar (Karabacak ve Kaygın, 2018; Yıldız vd., 2018) denetim süreçlerinin etkililiğini ön plana çıkarmaktadır (Güneş, 1985; Sabancı ve Rodoplu, 2013). Nitekim denetimin örgütsel amaçlara ulaşmada önemli bir süreç olduğu göz önüne alındığında bu alanda yapılacak çalışmalara ihtiyaç duyulduğu söylenebilir.

\section{Denetim}

Toplumu oluşturan kurum ve kuruluşlar işleyiş olarak birbirlerine bağlıdır ve eğitim ve bilim devletin işleyişinin temel noktasını oluşturmaktadır (Toprakçı, 2013). Eğitimi bilimsel bir yaklaşımla ele alıp, yönetim ve denetim aşamalarında Bakanlıkların Milli Eğitim Bakanlığı'ndan yararlanmaları önem arz etmektedir. Eğitim biliminin alt bilim dalları olarak eğitim yönetimi ve 
denetimi gelmektedir (Toprakçı ve Kadı, 2014). Denetimin eğitim sistemleri üzerinde önemli etkileri vardır. Denetlenmeyen ve kontrol edilmeyen hiçbir çalışmanın daha iyi bir hale getirilemeyeceği ve iyileştirmeyeceği belirtilmektedir (Başar, 2000). Denetim sayesinde çıktı kalitesi daha iyi olan örnekler fark edilerek genele yayılmakta ve niteliksiz olanlar ise saptanmaktadır (Schleicher, 2007). Kamu eğitiminde profesyonel denetim, iç ve dış denetim olmak üzere ikiye ayrııı. İç denetim kurumda görevli kişilerin alanındaki uzmanlıklarına göre, ulusal hedefleri ve amaçları ne kadar yanıt verebildiği; öğrencilerin başarıları ve okul yönetiminin değerlendirmesi ve denetlemesi şeklinde olmaktadır. Derslerin öğretimleri ile ilgili işlemlerinde iç denetim gerçekleşir (MEB, 2007a). Dış denetim ise oldukça çeşitlilik ve farklılık gösterdiği görülmektedir (Özmen ve Yasan, 2007). Dış denetim, eğitim politikalarını hazırlamak, dersleri bizzat gözetleyerek performans değerlendirmesi yapmak için bir kuruma verilen görev olarak ifade edilir (MEB, 2007a).

PISA sınavında başarı gösteren ülkelerin denetim anlayışına bakıldığında öz denetim ve dış denetim ifadeleri ile karşılaşılmaktadır. Örneğin, İngiltere, Çin, Japonya ve Hollanda'da, iç ve dış denetim olmak üzere iki yöntemin varlığından söz edilebilir (Katıtaş, Coşkun ve Turpçu, 2019). Bu ülkelerde okullar için değerlendirme raporları performans göstergesi olarak kullanılmaya başlanmıştır (Meşeci, 2007). İngiltere'de OFSTED Eğitimde Standartlar Bürosu bu süreç ile beraber faaliyet göstermeye başlamıştır. Bu kurum resmi okullar, yüksekokullar, yetişkin ve öğretmen eğitimi denetimi ve eğitimde kalite gibi birçok konuda raporlar sunan bir kurumdur. Hazırlanan raporlar kurumun internet sitesinde yayınlanmaktadır (Katıtaş, Coşkun ve Turpçu, 2019). Öğretmenlerin performanslarının değerlendirilmesi için velilerin, öğrencilerin ve yöneticilerin görüşleri alınmaktadır. Ayrıca öğretmenlerden öz değerlendirme yapmaları istenmektedir. Bunun yanında, derslerde kullanılan araç-gereçler uzmanlar tarafından izlenmektedir (Meşeci, 2007). Ingiltere'de 2009 yılından itibaren yetişkin eğitiminin planlanması, pratiğe dökülmesi ve bütçeye ilişkin hukuki işlemler yerel yönetimlerdedir. Eğitimden sorumlu iki bakanlığı bulunan İngiltere'de İş, Yenilik ve Beceriler Birimi (BIS) yetişkin eğitiminden sorumludur. Yetişkin eğitimi veren kurumlara bütçeyi BIS'e bağlı SFA kurumu sağlarken, denetimi yine BIS'e bağlı Ofqual (Nitelik ve Sınav Düzenleme Ofisi) sağlamaktadır (Vezne, 2017).

Öz denetime önem veren Çin, öğrencilerin, velilerin, okul yönetimi ve diğer paydaşların bu değerlendirmeye katılımını sağlamaktadır. Japonya'da hükümet ve belediyeler eğitim denetiminden sorumludur. Hükümet adına eğitim politikalarını oluşturan Eğitim, Kültür, Bilim ve Teknoloji Bakanlığı (MEXT) bulunmaktadır. Bu bakanlık eğitim sistemini denetleyecek yapıyı oluşturur, okullarda eğitim yönetimi sürecini, finansal kontrolü ve insan kaynakları yönetiminin denetimini gerçekleştirir. Japonya öz değerlendirme ile okulların her yıl kendilerini değerlendirmelerini ister. Okullar bu değerlendirmeyi internet sayfalarından yayınlar. Dış denetim işi müfettişler tarafından gerçekleşmektedir (Katıtaş vd., 2019). Hollanda'da ise eğitimi denetleme görevi "Eğitim Denetleme Kurulu" aracılığıyla yapılmaktadır. Bu kurum, eğitim kalitesi dışında kurumların işleyişi, bütçe kullanımı ve yasalara uygunluklarını denetler. Bu raporlar yıllık yayınlanır. Okullar dört yılda bir plan oluşturur ve performans, ilerleme, bütçe ve eğitim kalitesi ile ilgili yıllık rapor verir (Katıtaş vd., 2019). Eğitim Denetleme Kurulu'nda bulunan Başmüfettiş ve Müfettiş kurullarından her biri ilköğretim, ortaöğretim, yetişkin ve mesleki eğitim ile yükseköğretim gibi farklı bölümlerden sorumludur (MEB, 2007b). Finlandiya'da eğitim denetimi yerel düzeyde sorumlular ve okul yönetimi tarafından gerçekleştirilir. Okul yönetimi ve öğretmenler belirli aralıklarla toplanarak bilgi alışverişi ve değerlendirme yapmaktadır. Finlandiya eğitim sisteminde temel nokta öz değerlendirmedir. Bu süreçte öğretmenlerin güçlü ve zayıf yönlerinin öğrenilmesi ve kendilerini geliştirmesi sağlanır (Williams ve Engel, 2012).

Toprakçı (2008) eğitim denetimini, yapılmış veya yapılmakta olan eğitim etkinliklerinin, amacına ne kadar ulaştığını araştıran, tanımlayan ve bu süreci öndeyileyen bilim dalı olarak tanımlamıştır. Türkiye'de denetim ve rehberlik görevlerinin yürütülebilmesi için iki farklı eğitim denetimi yapılanması bulunmaktadır. Bunlar, Milli Eğitim Bakanlığı (merkez) ve II Milli Eğitim Müdürlükleri (taşra) yapılanmasıdır. Görevlendirmeler merkez teşkilatında Teftiş Kurulu Başkanlığı, taşrada ise Maarif Müfettişleri Başkanlıkları tarafından yürütülmektedir (Durnalı ve 
Limon, 2018). 2016 yllından itibaren denetim sistemi yeniden düzenlenerek, okul ve eğitim kurumlarında denetimlerinin daha verimli olması amacı ile denetim rehberleri kullanılmaya başlanmıştır. Bu denetim rehberlerine internet ortamında ulaşılmaktadır (TKB, 2020). Bu rehberlerin okul ve tüm eğitim kurumlarına yol göstermesi ve denetim sürecine katkı sağlaması amacıyla güncel tutulması önemlidir. Denetimi gerçekleștirenlere göre eğitim ile ilgili sorunların başında öğretmenlerin niteliği, yönetim yetersizliği ve Türk Eğitim Sistemi'nin kendi özgün modelini oluşturamamış olması gelmektedir (Apay, 2010). Halk eğitim merkezlerinde denetim konusunda yapılan çalışmalar denetimin bazen habersiz yapıldığını ve denetimde uygulama birliğinin olmadığını göstermektedir (Sabancı ve Rodoplu, 2013). Bu açıdan denetim rehberlerinin yasal mevzuat ve alanyazın temelinde ele alınarak güncelliğinin incelenmesi gerekmektedir.

\section{YÖNTEM}

Bu bölümde sırasıyla araştırmanın modeline, çalışmanın dokümanına ve verilerin toplanması ile analiz sürecine yer verilmiştir.

\section{Araştırma Modeli}

Mevcut araştırmada nitel araştırma yöntemlerinden doküman inceleme tekniği kullanılmıştır. Nitel araştırma yaklaşımı, olayları, olguları ve durumları derinlemesine yorumlamayı ve anlamlandırmayı hedeflemektedir (Neuman, 2008). Bu tür araştırmalar insanların, algıların ve olayların, kendi ortamlarında ayrıntılı incelenmesinin olduğu, farklı alanları birleştiren araştırmalardır (Merriam ve Grenier, 2019). Çalışmayı yapan kişi, olay ve olguların gerçek durumunu değiştirmeden sunar ve bu hallerini korumaya çalışır (Miles ve Huberman, 1994). Nitel araştırmanın verilerini gözlem, görüşme ve dokümanlar oluşturmaktadır (Berg ve Lune, 2015; Merriam, 2009). Doküman incelemesi, yazilı ya da internet ortamındaki kaynakları analiz etmek ve değerlendirmek için kullanılan bir nitel araştırma modelidir. Diğer nitel araştırma yöntemlerinde olduğu gibi, anlam çıkarmak ve konu hakkında anlayışa sahip olmak üzere derinlemesine toplanan verilerin incelenmesi ve yorumlanmasına olanak sağlar (Bowen, 2009). Dokümanlar, kişisel ve kurumsal olmak üzere ikiye ayrılmaktadır (Corbetta, 2003). Kişisel dokümanlara örnek olarak mektuplar, anılar, günlükler ve fotoğraflar gösterilebilir (Bogdan \& Biklen, 2007). Kurumsal dokümanlara ise kanunlar, yönetmelikler, kimlik kartları ve faturalar örnek verilebilir (Guba \& Lincoln, 1981). Bu kapsamda kamu ve arşiv dokümanları üzerinde doküman incelemesi yöntemi kullanılabilir. Denetim rehberleri, MEB Teftiş Kurulu Başkanlığı́nın kurumların denetimde uygulama birliğini sağlamak amacıyla yayınladığı kamu belgeleri olduğundan bu araştırmada doküman incelemesi yönteminin aşamalarına uygun bir yol izlenmiştir.

\section{Çalışma Dokümanı}

MEB Teftiş Kurulu Başkanlığı, 2016 yılında Bakanlığa bağlı kurumların denetiminde yol göstermesi amacıyla 652 sayılı Kanun Hükmünde Kararname ile 16 adet denetim rehberi yayımlamıştır. Bu rehberler maarif müfettişlerinin denetim sürecinin nasıl ilerleyeceğine ilişkin esasları içermektedir. Mevcut çalışmanın dokümanı ise Halk Eğitim Merkezleri için hazırlanan denetim rehberi oluşturmaktadır. Söz konusu dokümana Milli Eğitim Bakanlığı Teftiş Kurulu Başkanlığı internet sitesinin "Yayınlarımız" sayfasından 24.04.2020 tarihinde ulaşılmıştır. Yasal belgelere ve alanyazına ulaşmak için çevrim içi ortamlar (Google Akademik, Mevzuat - resmi siteleri, Google ve Yandex'de denetim rehberi, halk eğitimi merkezi denetim rehberi, halk eğitimi merkezi denetim vb. anahtar kelimeler) ile araştırmacıların gerçek ve sanal kütüphanesinde bulunan kaynaklar kullanılmıştır. Ulaşılan belgeler (rehber hariç olmak üzere) sınırlığında bir incelemenin gerçekleştirildiğini belirtmek gerekir.

\section{Verilerin Toplanması ve Analizi}

Doküman incelemesi, araştırılması hedeflenen yazılı materyallerin analizini kapsamaktadır. Başarılı bir doküman incelemesi için dokümanı sınırlama, orijinalliğini teyit etme ve dokümanı detaylı okuma aşamaları oldukça önemlidir. Dokümanlara ulaşma aşamasında "Halk Eğitim 
Merkezleri Rehberlik ve Denetim Rehberine" Milli Eğitim Bakanlığı Teftiş Kurulu Başkanlığı'nın resmi internet sitesinden, rehberde bahsi geçen ilgili kanun, yönetmelik, yönerge, genelge ve diğer belgelere ise yine bakanlığın kendi sitesinden ulaşılmıştır. Dokümanların orijinalliği (gerek uzmanlar gerekse diğer çevrimiçi olanaklar bağlamında) teyit edilmiştir. Dokümanların detaylı okunması aşamasında öncelikle ilgili rehber ardından rehberde bahsi geçen mevzuat detaylı olarak incelenmiştir.

Çalışma dokümanını analiz etmek için içerik analizi uygulanmıştır. İ̧̧erik analizi, araştırma verisinden içeriği ile ilgili yinelenebilir ve uygun sonuçlar çıkarmak için kullanılan nitel analiz yöntemlerindendir (Krippendorff, 2018). Bu yöntem verilerin kodlanması, temaların bulunması, kodların ve temaların düzenlenmesi, bulguların tanımlanması ve yorumlanması süreçlerinden oluşmaktadır (Yıldııım ve Şimşek, 2013). Bu çalışmada öncelikle kodlar oluşturulmuştur. Kodların oluşturulmasında diğer denetim rehberlerini inceleyen ekiplerle birlikte çalışma yapılmıştır. Tablo 1 'de çalışmanın kod, kategori ve temalarına yer verilmiştir.

Tablo 1 incelendiğinde, rehberin tutarlılık ve tutarsızlık temaları altında hukuki belgeler ve alanyazın ile olan ilişkisi alt temalar olarak biçimlenmiş, "Yasal Dayanağa Uygunluk" , "Ana Belge Temelli Tutarsızlık", "Diğer Yasal Belgeler Temelli Tutarsızlık", "Alanyazına Uygunluk" ve "Alanyazında Tutarsızlık" şeklinde kategoriler oluşmuştur. Rehberde geçen yasal dayanaklardan incelenme tarihi itibariyle yürürlükte olan hukuki belgeler "Yasal Dayanağa Uygunluk" kategorisi ile tanımlanmıştır. Yasal dayanak olarak gösterilen Yaygın Eğitim Kurumları Yönetmeliği'nin rehberin yayın tarihinden sonra yürürlükten kaldırılmış olması "Ana Belge Temelli Tutarsızlık" kategorisi altında "Yaygın Eğitim Kurumları Yönetmeliği" kodu ile belirtilmiştir. Rehberde geçen ama güncel olmayan diğer yasal dayanaklar ise "Diğer Yasal Dayanaklara Göre Güncel Olmama" kodunu oluşturmuştur. Verilerin bulguya dönüşmesinde anlaşılmayı kuvvetlendirmek için verilerin sayısallaştırılması yoluna da gidilmiştir. Son olarak veriyi kullanma aşamasında belirlenen temalara göre uygun olan alıntılarla analiz desteklenmiş ve yorumlanmıştır.

\section{Çalışmanın Geçerlik ve Güvenirliği}

Lincoln ve Guba (1985)'e göre nitel araştırmalarda, inandırıcılı̆ı̆n, aktarılabirliğin, tutarlı̆ı̆n ve teyit edilebilirliğin olması gerekmektedir. Çalışmanın geçerliğini ve güvenilirliğini sağlamak için çeşitli teknikler kullanılmıştır. Uzman incelemesi ve meslektaş teyidi ile verilerin iç geçerliği (inandırıcılık) sağlanmıştır. Meslektaş teyidi; verilerin karşılaştırılarak uyumunun ortaya çıkarılmasını hedeflemektedir. Uzman incelemesi ise araştırma sürecine eleştirel gözle bakan ve araştırmacıya geribildirimde bulunan uzman görüşünü belirtmektedir (Yıldırım ve Şimşek, 2013). Araştırmanın geçerliğinin sağlanması için ilk olarak meslektaş teyidine gidilmiştir. Bunun için MEB Teftiş Kurulu Başkanlığı'nın farklı kurumlara yönelik denetim rehberlerini inceleyen araştırmacılar düzenli aralıklarla her hafta belirlenen gün ve saatte internet ortamında canlı toplantı araçları üzerinden bir araya gelmiştir. Tekrar izlenebilmesi için bu toplantılar kaydedilmiştir. Toplantılarda rehberlerin hangi yönlerden incelenebileceğine ilişkin tartışmalar yapılmıştır. Sonrasında ise araştırmacılar inceledikleri rehberlere yönelik içerik analizi yaparak kodlar ve temalar oluşturmuş ve bunların benzer ve farklı yönleri üzerinde durmuştur. Anlaşmazlığa düşülen noktalar değerlendirilmiş ve fikir birliğine varıncaya kadar toplantılar devam etmiştir. Halk Eğitim Merkezleri Rehberlik ve Denetim Rehberinin temel resmi dayanağı olan Yaygın Eğitim Kurumları Yönetmeliği 2018 yılında kaldıılmış yeni Yönetmelik yayınlanmıştır. Bu durum toplantıda tartışılmış ve "ana belge temelli tutarsızlık koduyla incelenmesine karar verilmiştir. Uzman görüşü için denetim alanında yetkin ve yayımları olan bir akademisyen ile bir maarif müfettişi bu toplantılarda yer alarak toplantı sürecinde geribildirimlerde bulunmuşlardır. Geçerlik ve güvenirliğin sağlanması için değerlendirilen rehberlerin görüş birliğine dayalı olarak analiz edilmesine ve ayrıntılı bir raporun oluşturulmasına dikkat edilmiştir. Son toplantının ardından çalışma alanında uzman akademisyenlere gönderilmiş ve onların görüşleri de çalışmaya dahil edilmiştir. Diğer araştırmacıların talebi olursa veya gelecekte başka bir araştırmada karşılaştırma yapılması gerekirse diye araştırmanın ham verileri saklanmıştır böylece dış güvenilirlik (teyit edilebilirlik) arttırılmaya çalışılmıştır. 
Tablo 1. Denetim Rehberi ile Yasal Mevzuat ve Alanyazının Karşılaştırma Süreci

\begin{tabular}{|c|c|c|c|c|}
\hline Tema & $\begin{array}{c}\text { Alt } \\
\text { Tema }\end{array}$ & $\begin{array}{c}\text { Kateg } \\
\text { ori }\end{array}$ & $\begin{array}{c}\text { Kodla } \\
\mathbf{r}\end{array}$ & Temayla ilişkili ifadeler ve Gönderme yapılan yasal belge/ ilgili madde \\
\hline \multirow{4}{*}{ 美 } & \multirow[t]{2}{*}{ 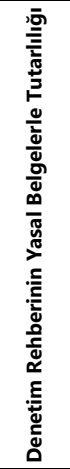 } & \multirow[t]{2}{*}{ 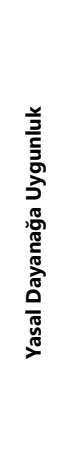 } & 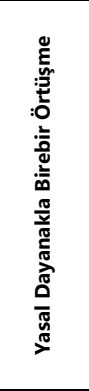 & 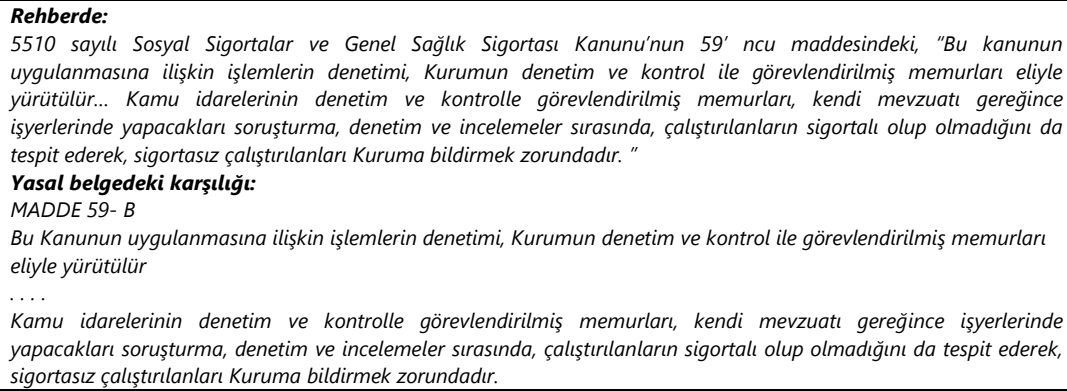 \\
\hline & & & \multicolumn{2}{|r|}{$\begin{array}{l}\text { Sonuç: Rehberde geçen yasal dayanak ile Anayasa ve diğer yasal belgelerdeki ifadeler karşılaştıııldığında birebir aynı olduğu } \\
\text { görülmüştür. }\end{array}$} \\
\hline & \multirow[t]{2}{*}{ 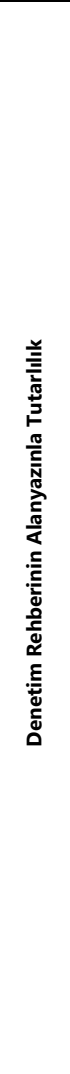 } & \multirow[t]{2}{*}{ 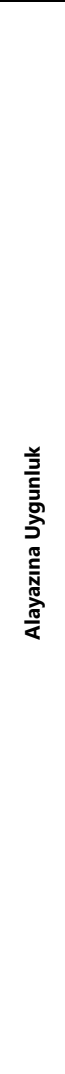 } & 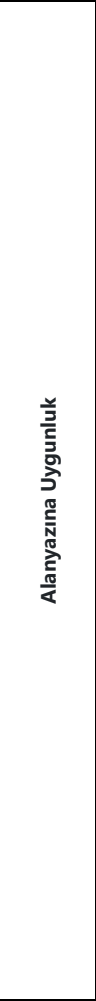 & 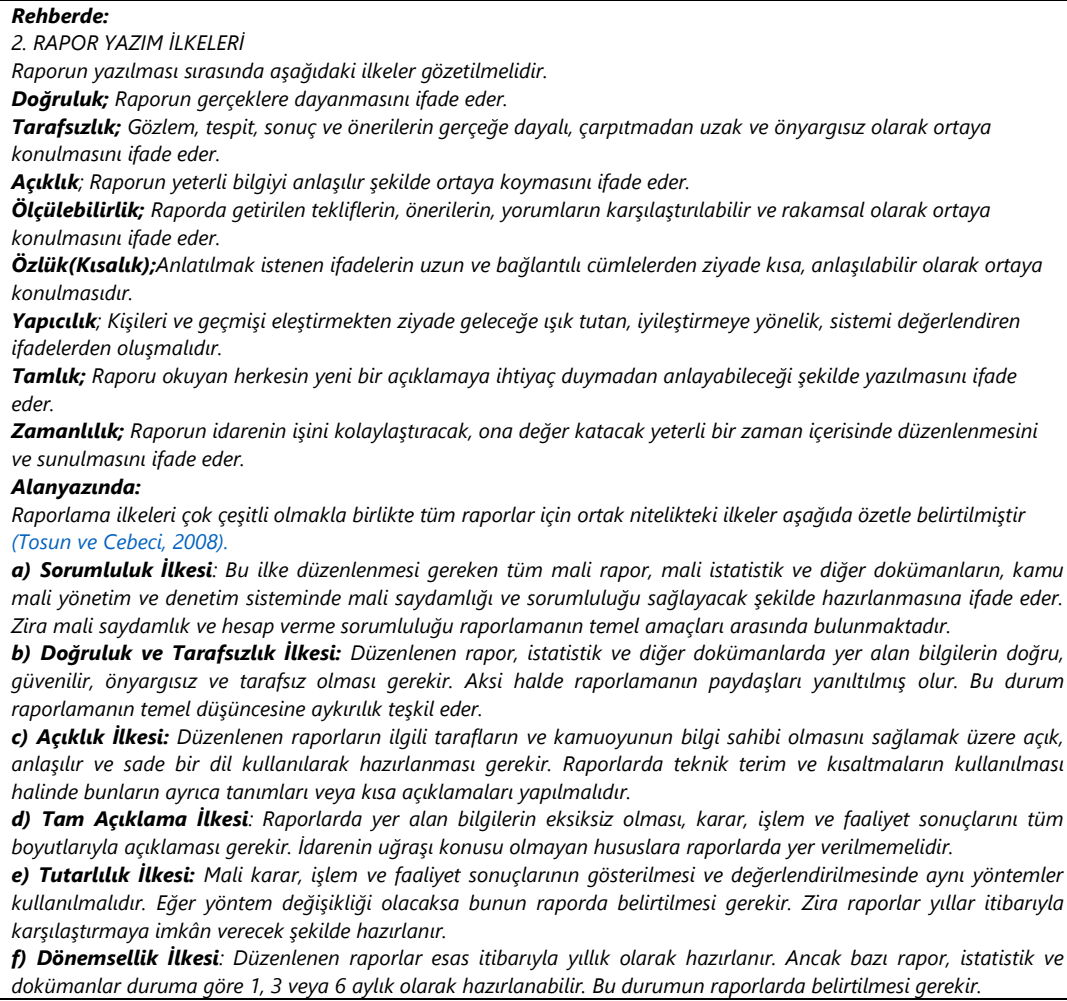 \\
\hline & & & \multicolumn{2}{|r|}{$\begin{array}{l}\text { Sonuç: Alanyazın ile Denetim Rehberi incelendiğinde tamamen aynı ifadelerle olmasa da yakın ifadelerle tutarlı olduğu } \\
\text { görülmektedir. }\end{array}$} \\
\hline \multirow{4}{*}{ 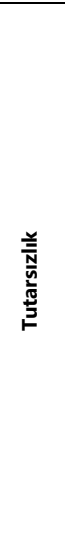 } & \multirow{2}{*}{ 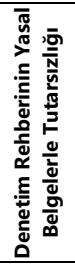 } & \multirow{2}{*}{ 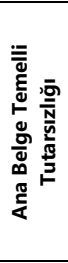 } & 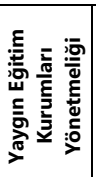 & $\begin{array}{l}\text { Rehberde: } \\
\text { MEB Yaygın Eğitim Kurumları Yönetmeliği } \\
\text { Yasal belgedeki karşıı̆ığ: } \\
\text { Hayat Boyu Öğrenme Kurumları Yönetmeliği }\end{array}$ \\
\hline & & & \multicolumn{2}{|r|}{$\begin{array}{l}\text { Sonuç: } 11 \text { Nisan } 2018 \text { tarihinde Hayat Boyu Öğrenme Kurumları Yönetmeliği yayınlanması ile birlikte Rehberin temel dayanağı } \\
\text { MEB Yaygın Eğitim Kurumları Yönetmeliği yürürlükten kalkmıştır. }\end{array}$} \\
\hline & 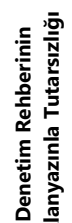 & 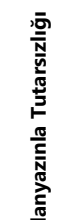 & \multicolumn{2}{|r|}{ 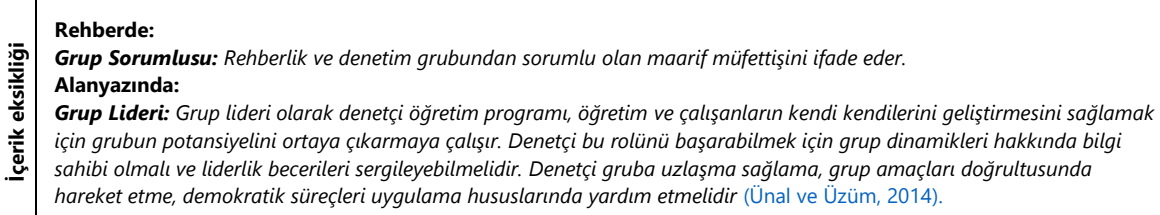 } \\
\hline & & & \multicolumn{2}{|r|}{ nuç: Rehberlik ve Denetim Rehberinde geçen bazı tanımlar alanyazına göre kısaca verilmiş yeterli açıklama yapıımamıştır. } \\
\hline
\end{tabular}

Birlikte hareket edilerek şekilenen rehberlerle ilgili çalışmaların bazıları yayımlanmışıı (Toprakçı ve Bakır 2020; Tonbul ve Ata 2020; Özdemir ve Altuntaş 2020; Akçay Güngör 2020; Kahraman 2020; Tonbul ve Keleş 2020; Ölmez ve Algam 2020; Toprakçı ve Özerten 2020). Bu 
çalışma hakem süreci ve yazım ile ilgili iş ve işlemlerin uzamasından dolayı sonra yayımlandığından onlara vurgu yapmak gereği duyulmuştur.

\section{BULGULAR VE YORUM}

Bu bölümde "Halk Eğitim Merkezleri Rehberlik ve Denetim Rehberinin" yasal belgeler ile alanyazın temelinde analiz edilmesi sonucu ortaya çıkan temaların ve kodların dağılımına ve oluşan bulguların yorumlanmasına yer verilmiştir.

\section{Tema 1: Denetim Rehberinin Yasal Belgelerle ilişkisi}

Denetim rehberinde gönderme yapılan hukuki dayanaklar yasal belge olarak tanımlanmıştır. Bu çalışmada ilk olarak denetim rehberinin yasal belgeler ile tutarlılığına bakılmıştır. Yasal dayanağa uygun olan olanlar tutarlıık, uygun olmayanlar ise ana belge temelli tutarsızlık ve diğer yasal belgeler temelli tutarsızlık kategorisini oluşturmuştur. Ana belge temelli tutarsızlık kategorisi altında "Yaygın Eğitim Kurumları Yönetmeliği" , "Halk Eğitimi Faaliyetlerinin Uygulanmasına Dair Yönerge" kodları, diğer yasal belgeler temelli tutarsızık kategorisi altında "Mesleki ve Teknik Eğitim Yönetmeliği", "Millî Eğitim Bakanlığı Rehberlik Hizmetleri Yönetmeliği" ve "Diğer Yasal Dayanaklara Göre Güncel Olmama" kodları yer almaktadır. Tablo 2 'de Halk Eğitim Merkezleri denetim rehberinin yasal belgeler temelinde incelenmesi sonucunda elde edilen bulgular yer almaktadır.

Tablo 2. Halk Eğitim Merkezleri Denetim Rehberinin Yasal Belgelerle Iliş̧kisi

\begin{tabular}{|c|c|c|c|c|}
\hline Tema & Alt Tema & Kategori & Kod & Sıklık \\
\hline \multirow{6}{*}{ 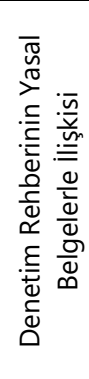 } & $\begin{array}{l}\text { Yasal Belgelerle } \\
\text { Tutarlılık }\end{array}$ & Yasal Dayanağa Uygunluk & Yasal Dayanakla Birebir Örtüşme & 20 \\
\hline & \multirow{5}{*}{$\begin{array}{l}\text { Yasal Belgelerle } \\
\text { Tutarsızlık }\end{array}$} & \multirow[b]{2}{*}{$\begin{array}{l}\text { Ana Belge Temelli } \\
\text { Tutarsızlık }\end{array}$} & Yaygın Eğitim Kurumları Yönetmeliği & 46 \\
\hline & & & $\begin{array}{l}\text { Halk Eğitimi Faaliyetlerinin } \\
\text { Uygulanmasına Dair Yönerge }\end{array}$ & 27 \\
\hline & & \multirow{3}{*}{$\begin{array}{l}\text { Diğer Yasal Belgeler } \\
\text { Temelli Tutarsızlık }\end{array}$} & Mesleki ve Teknik Eğitim Yönetmeliği & 7 \\
\hline & & & $\begin{array}{l}\text { Millî Eğitim Bakanlığı Rehberlik } \\
\text { Hizmetleri Yönetmeliği }\end{array}$ & 2 \\
\hline & & & $\begin{array}{l}\text { Diğer Yasal Dayanaklara Göre Güncel } \\
\text { Olmama }\end{array}$ & 8 \\
\hline \multicolumn{3}{|c|}{ Tutarsızlık Toplamı } & & 90 \\
\hline
\end{tabular}

Tablo 2'ye göre, rehberde yer alan maddelerin yasal belgeler ile görece az örtüştüğü görülmektedir $(n=20)$. Yasal dayanağa uygunluk, rehberin içinde geçen hukuki dayanakların güncel ve geçerli olması şekliden kullanılmıştır. Bu kapsamda, rehberde geçen "Kurumlar ve bu kurumlarda görevli personel, Bakanlığın denetimi ve gözetimi altındadır." ifadesi ile 5580 sayılı Özel Öğretim Kurumları Kanunu'nun 11. maddesindeki ifade bire bir örtüşmektedir. Rehberin yasal belgelerle çok az örtüşmesinin bir nedeni yönetmeliğin rehberin yayın tarihinden sonra değişikliğe uğramış olmasıdır. Bu kapsamda rehberin güncellenmediği anlaşılmaktadır.

Yine Tablo 2 incelendiğinde, tutarsızlık teması içinde yer alan yasal belgelerle tutarsızlık alt teması, incelenen rehberin içinde geçen yasal dayanakların tutarsızlığını ifade etmektedir. Halk Eğitim Merkezleri denetim rehberindeki yasal dayanaklar incelendiğinde 90 madde üzerinde tutarsızlık yaşandığı anlaşımıştır. Tutarsızlık alt teması ana belge temelli ve diğer belge temelli tutarsızlık kategorilerinde incelenmiştir. Incelenen rehberin temel dayanağı 2011 yılında yürürlükte olan Yaygın Eğitim Kurumları Yönetmeliği ve Halk Eğitimi Faaliyetlerinin Uygulanmasına Dair Yönergedir. Yaygın Eğitim Kurumları Yönetmeliği 11 Nisan 2018 tarihinde kaldırılmış, 30388 sayılı Hayat Boyu Öğrenme Kurumları Yönetmeliği yayımlanmıştır. Rehberin yayın tarihi itibariyle yeni yönetmelik yayınlanmamış olması nedeniyle ana belge temelli tutarsızlık kategorisi altında "Yaygın Eğitim Kurumları Yönetmeliği" ve "Halk Eğitimi Faaliyetlerinin Uygulanmasına Dair Yönerge" kodları oluşmuştur. Rehberde Yaygın Eğitim 
Kurumları Yönetmeliği'ne 46, Halk Eğitimi Faaliyetlerinin Uygulanmasına Dair Yönergesine 27 gönderme yapılmıştır. Denetim rehberinin bu iki yasal belgeyi güncellemediği görülmüştür.

Denetim rehberinde Hayat Boyu Öğrenme Kurumları Yönetmeliği dışında da yasal dayanaklarda tutarsızlıklar bulunmuştur. Bu tutarsızlıklar Diğer Yasal Belgeler Temelli Tutarsızlık kategorisi ile isimlendirilmiştir. Bu kategoriler altında Mesleki ve Teknik Eğitim Yönetmeliği, Millî Eğitim Bakanlığı Rehberlik Hizmetleri Yönetmeliği ve diğer yasal dayanaklara göre güncel olmama kodları oluşmuştur. Bu yasal dayanaklardan en fazla gönderme yapılan Mesleki ve Teknik Eğitim Yönetmeliğidir $(n=7)$. Rehberde Mesleki ve Teknik Eğitim Yönetmeliğine gönderme yaparak aday çırak, çırak ve kalfalara ait iş ve işlemler Mesleki ve Teknik Eğitim Genel Müdürlüğüne devredilmiş ve mesleki eğitim merkezleri de Genel Müdürlüğüne bağlanmıştır. Halk eğitim merkezleri denetim rehberinde bazı yasal dayanaklar rehberin yayınlandığı tarihten sonra güncellenmiş ya da yürürlükten kaldırılmıştır. Örneğin, "Geçici korum altındaki Suriyelilerin meslek eğitime kayıt işlemleri" için denetim rehberinde gönderme yapılan MEB Mesleki ve Teknik Eğitim Genel Müdürlüğünün 10/08/2016 tarihli ve E.8542490 sayılı yazısı 03/02/2017 tarihinde güncellenmiştir. Bunun yanında denetim rehberinde yer alan MEB Eğitimde Kalite Yönetim Sistemi Yönergesi 20.02.2018 tarihinde yürürlükten kaldırılmıştır. Yasal belgelerdeki güncellemelerin denetim rehberine yansıtılmaması denetimde uygulama birliğini ve standartlaşmayı amaç edinen bu dokümanın güvenirliğine ve kullanışlılığına olumsuz yönde etkileyebilir.

\section{Tema 2: Denetim Rehberinin Alanyazınla ilişkisi}

Denetim rehberinin alanyazına göre incelenmesinden sonra "Denetim Rehberinin Alanyazınla İlişkisi" teması altında "Alanyazınla tutarlılık" ve "Alanyazınla tutarsızlık" alt temaları oluşmuştur. Tablo 3 'te denetim rehberi ile alanyazın arasındaki tutarlıı̆ın karşılaştırılması sonucunda elde edilen bulgular yer almaktadır.

Tablo 3. Denetim Rehberi ile Alanyazın Arasındaki Tutarlığın Karşılaştırılması

\begin{tabular}{|c|c|c|c|}
\hline Tema & Alt Tema & Kategori & Kod \\
\hline \multirow{5}{*}{ 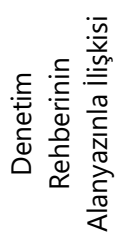 } & Alanyazın ile Tutarlılık & Alanyazına Uygunluk & Alanyazına Uygunluk \\
\hline & \multirow{4}{*}{ Alanyazın ile Tutarsızlık } & \multirow{4}{*}{ Alanyazında Tutarsızlık } & İçerik Eksikliği \\
\hline & & & Alan yazına Atıfsızlık \\
\hline & & & Kavram Tutarsızlığı \\
\hline & & & Alanyazına Aykırılık \\
\hline
\end{tabular}

Tablo 3'e göre, denetim rehberinin alanyazın ile tutarlıığı alt teması altında "Alanyazına uygunluk" kategorisi bulunmaktadır. Bu kategori alanyazınla uyum sağlayan rehber içeriği için kullanılmaktadır. Örneğin, Maarif Müfettişlerinin görevleri yasalarla belirtilmiş ve aşağıda da rehberde geçtiği bölümün bir kısmı verilmiştir;

"Maarif Müfettişlerinin Görevleri; a) 652 sayll Kanun Hükmünde Kararnamenin 17. maddesinde belirtilen görevleri yapmak b) Rehberlik, denetim, inceleme, soruşturma çalışmaları neticesinde düzenleyecekleri raporları en geç yirmi gün, kapsamlı işlerde ise verilen ek süre içinde tamamlamak c) Rehberlik ve denetim çalışmalarında mesleğin gerektirdiği özeni ve titizliği göstermek. ç) Refakatlerine verilecek müfettiş yardımcılarının yetişmelerini sağlamak d) Rehberlik ve denetimlerde hizmetlerin süreç ve sonuçlarının mevzuata uygunluğunu kontrol etmek, tespit ettiği özellik arz eden hususları grup sorumlusuna bildirmek. e) Raporu, rehberlik ve denetim raporlama standartlarina uygun olarak düzenlemek. f) Mevzuatla verilen diğer görevleri yapmak."

Maarif müfettişlerinin görevleri arasında rehberlik çalışmaları ön planda bulunmaktadır. Alanyazında Müfettişlerin rehberlik görevlerinin ne kadar önemli olduğu belirtilmiştir:

"Çağdaş anlayışa göre bu rehberliğin müfettişler tarafından yapılması (Karagözoğlu, 1972) uzmanlıklarına uygunluğu açısından daha doğru görülmektedir. Günümüz eğitimcilerinin 
pek çoğuna göre teftiş, eğitim sürecinden daha iyi ürün alabilmek için, bu süreci oluşturan üyelere rehberlik etmektir (Bilir, 1998). Burada sadece aday öğretmenler değil, tecrübeli ögrretmenler de, eğitsel ve yönetsel desteği sağlayabilecek bir uzmanın rehberliğine sürekli ihtiyaç duymaktadırlar (Sullivan ve Glanz, 2000). Denetimde, müfettişler rehberlik rollerine daha fazla önem verdiği takdirde ögrretmen ve idareciler, müfettişleri okullarının gelişmesi, kalitesinin ve başarısının artması için yol gösteren, eğitim alanındaki yenilikleri ve gelişmeleri ögretmen ve idarecilere aktaran bir lider olarak göreceklerdir (Taymaz, 2005)."

Öğretmenlerin bireysel ve mesleki olarak başarııının artmasında rehberlik oldukça önemli bir yere sahiptir. Rehberdeki müfettişlerin görevleri ve alanyazındaki müfettişlerin rehberlik görevinin uyum sağladığı görülmüştür. Rehberin genel olarak alanyazınla tutarlı çıkmasının nedeni denetim ile ilgili alanyazındaki çalışmalar hazırlanırken hukuki dayanaklardan da yararlanılmasıdır.

Yine Tablo 3 incelendiğinde, alanyazında rehber ile farklılık gösteren ifadelere rastlanmıştır. Bu ifadeler alanyazınla tutarsızlık kategorisi altında verilmiştir. Bu kategori kapsamında "Iç̧erik eksikliği", "Atıfsızlık", "Kavram tutarsızlığı" ve "Aykııılık" olmak üzere dört kod tespit edilmiştir. Alanyazında tutarsızlık alt teması altında rehbere bakıldığında bu tutarsızığın bazılarının rehberde bazı ifadelerin olmamasından kaynaklı olduğu görülmüş ve içerik eksikliği kodu oluşmuştur. Rehberde yer alan rehberlik ve denetim ilkelerine şu şekildedir:

"a) Bireysel ve kurumsal farkllıklar ile çevresel faktörleri dikkate almak. b) Yol gösterici ve önleyici rehberliği öne çıarmak, düzeltmeyi, iyileştirmeyi ve gelişstirmeyi esas almak. c) lyi uygulama örneklerini yaygınlaştırmak. ç) Usulsüzlük ve yolsuzlukları önleme yönelimli olmak. d) Açıklık, şeffaflık, eşitlik, demokratiklik, bağımsızlık, bütünlük, güvenilirlik ve tarafsızlı̆ı esas almak. e) işbirliği ve katılımı öngörmek. f) Başarıyı öne çıkarmak, özendirmek, teşvik etmek ve ödüllendirmek. g) Personelin mesleki yeterliğini gelişstirmek. ğ) Objektif olmak. h) Gelecek yönelimli olmak. ı) Etkililik, ekonomiklik ve verimlilik esaslarını dikkate almak. i) Millî birlik ve bütünlügümüzün temel unsurlarından biri olan Türkçenin doğru kullanılması hususunda gerekli duyarllığı göstermek. j) Kurumlarda rehberlik ve denetim faaliyetlerini birlikte yürütmek"

Rehberde bu ilkelerin açıklamalarına yer verilmemiştir. Aynı zamanda denetim ile ilgili alanyazın taramasında denetim ile beraber hesap verebilirlik ve şeffaflığında ön planda olduğu görülmüştür.

"Hesap verebilirlikte kamu kaynaklarını verimli kullanılabilmesi, yolsuzlukların asgari düzeye indirilmesi ve kamu yönetimine güvenin artırlması öncelikli ve önemlidir (Tutar ve Altınöz, 2017). Neden hesap verileceği boyutunda da yasa ve yönetmeliklere uygunluk, meslektaş örgütleri standartlarına uygunluk, şeffaflık, raporlama gereksinimleri, başarıya dair standartlara uygunluk gibi unsurlar yer almaktadır. Hangi konuda hesap verileceği ise belirlenen tüm standartlar ve hedeflere ulaşma durumu ve sonuçları olarak değerlendirilmektedir. Hesap verebilirlikte hesap soran ve hesap veren arasında kuralların, yükümlülüklerin belli olduğu, hesap soranın her zaman soru sorabildiği, hesap verenin de cevap verebilir olduğu bir yapı söz konusudur (Bovens, 2007)."

Denetimde yer alması gereken hesap verebilirlik ve şeffaflığa rehberde yeteri kadar değinilmemiştir. Bunun nedeni rehberi hazırlayan kişilerin alanyazını incelemeden bunu yayınlaması olabilir. Bu durum denetim ile ilgili görevli müfettişin temel kaynağı olan rehberin bilimselliğine gölge düşürmektedir. Alanyazınla tutarsızlık alt teması altındaki alanyazına atıfsılık kodu rehberin konusu ile ilgili yapılmış bilimsel çalışmalarla, çelişen durumlara ya da belgelere gönderme yapılmaması durumunu ifade etmektedir. Denetim rehberinde geçen "rehberlik" tanımına bakıldığında,

"Rehberlik: Bakanlığın görev alanına giren konularda Bakanlı personeline, Bakanlığa bağı̆ okul ve kurumlarına, özel öğretim kurumlarına, gerçek ve tüzel kişiler ile gönüllü kuruluşlara faaliyetlerinde yol göstermek, programlar oluşturmak, eğitim-öğretim ile diğer çalışma ve uygulamalarda, kaynakların etkili bir biçimde kullanılmasını sağlamak, verimliliği artırmak, mevzuata uygunluğu sağlamak, eğitim-öğretim düzeyini yükseltmek ile denetim ve rehberlik 
çalışmaları sırasında görevlileri bilgilendirmek, onları hizmet içinde yetiştirmek için yapılan her türlü mesleki yardım ve önerileri kapsayan hizmetler bütünüdür."

ifadeleriyle tanım yapılmıştır. Bu tanımın nereden alındığına dair bilgilendirme yapılmamıştır. Bu kodun oluşmasının en büyük nedeni rehberin hazırlanmasında hukuki dayanakları ön planda tutması olabilir.

Alanyazın ile tutarsızlık kategorisi altında kavram tutarsızlığı koduna bakıldığında rehberdeki bazı ifadelerin alanyazındaki ifadelerle örtüşmediği görülmüştür. Rehberde denetimin tanımına bakıldığında,

"Denetim: Genel olarak kamuda, özel ve tüzel kişiliği bulunan kurum ve kuruluşlarda yapılmakta olan işlerin; kaynak, imkân ve şartlar dikkate alınarak, yasal çerçeve ile belirlenen amaç, öngörülen temel ilke ve hedeflere uygunluğunu, doğruluğunu, düzenliliğini, verimliliğini, ekonomikliğini, etkinliğini; objektif, geçerli, güvenilir ölçütlere göre karşılaştırma yapabilme, ulusal standartlara ve planlanan esaslara göre durumunu ortaya koyma, giderilebilir eksiklikler için rehberlikte bulunma, değişim ve gelişim için misyon ve vizyon kazandırmaya ilişkin öneriler getirme sürecidir."

Alanyazındaki denetim tanımına bakıldığında,

Denetim, "Düzeltme, geliştirme amaçlı etkinlikler bütünüdür." Başar (2000). Denetim, örgütsel eylemlerin kabul edilen amaçlar doğrultusunda saptanan ilke ve kurallara uygun olup olmadığının anlaşılması süreci olarak düşünülebilir (Aydın, 2000). Başka bir tanımda Bursalığlu (1982) denetim, kamu ve kurum yararına insan davranışlarını kontrol etme süreci olarak ifade edilmektedir. Denetim kavramı, soruşturma işlemlerini de kapsamakla birlikte kurumun amaçlarına ulaşması için personele yapılan mesleki rehberlik ve yardım olarak nitelendirilebilir (Taymaz, 2005).

Denetim rehberi ile alanyazın karşılaştııılığında, rehberde denetim tanımı ile rehberlik tanımı ayrı ayrı verilmiş kavram tutarsızlığı oluşmuştur. Alanyazında ise (Taymaz, 2005) denetim ile rehberlik aynı tanım içerisinde yer almaktadır. Bu kodun oluşmasının temel nedeni alanyazındaki ifadelerin farklı kaynaklar araştırılmadan alınması ya da doğru kaynaklardan alınmaması olabilir. Alanyazına aykırılık kodu alanyazındaki ifade ile rehberdeki ifadenin çelişmesi durumunda kullanılmaktadır. Rehberde tutarsızlık teması altında yer alan alanyazına aykırılık alt teması incelemiş alanyazına aykırı durum görülmemiştir.

Mevcut çalışma kapsamında elde edile bulgular Şekil 1'de özetlenmiştir:

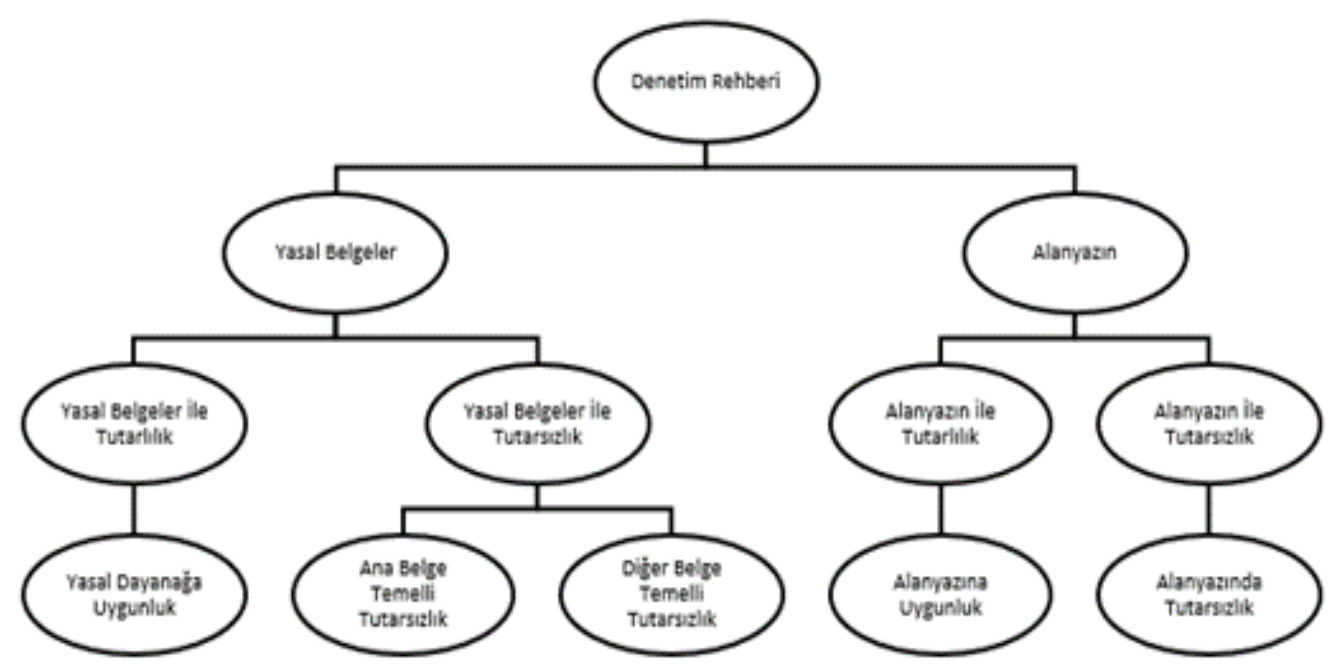

Şekil 1. Denetim rehberinin yasal belgeler ve alanyazın ile karşılaştırılması 


\section{TARTIŞMA, SONUÇ VE ÖNERILER}

Bu araştırma, Halk Eğitim Merkezleri için düzenlenen denetim rehberinin yasal belgeler ve alanyazın temelinde incelenmesini konu edinmiştir. Okul ve kurumlarda amacına uygun ve güvenilir bir yapılabilmesi için denetim rehberlerinin önemi oldukça fazladır. Çalışmada incelenen "Halk Eğitim Merkezleri Rehberlik ve Denetim Rehberinde" yasal belgeler açısından bazı tutarsızlıkların olduğu görülmüştür. Bu tutarsızlığın nedeni rehberin yayın tarihinden sonra yeni yönetmeliğin ve yönergelerin yayınlanmasından kaynaklandığı söylenebilir. Bu durum rehberin 2016 yılından sonra yayımlanan yasal belgelere göre güncellenmediğini göstermektedir. Altınışık ve Binbir (2015) çalışmasında 2000-2014 yılları arasında Türk Eğitim Sisteminde mevzuatların sıklıkla değiştirildiği bulgusuna ulaşıımışıı. Aynı şekilde Durnalı ve Limon'un (2018) çalışmasında, yasal belgelerde oldukça fazla yaşanan değişikliklerin, özellikle uygulayıcılar için gerekli olan kesinlik, fonksiyonellik, kararııık ilkelerini göz ardı ettiğini belirtmiş, eğitimde devamlılık esas alınarak programlarda ve mevzuatta yapılan değişimlerin ihtiyaçlara yönelik olmasını, değişikliklere geçişin yumuşak olması gerektiğini vurgulamıştır. Halk Eğitim Merkezleri Rehberlik ve Denetim Rehberinde güncel olan yasal dayanaklar Halk Eğitim Merkezleri ile dolaylı ilgili dayanaklardır. Örneğin, 5510 sayılı Sosyal Sigortalar ve Genel Sağlık Sigortası Kanunu kurumda çalışan personellerin haklarını korumaktadır. Denetim rehberinde bunun kontrolünde denetim yapılacağı belirtilmiştir. Denetim rehberi ile yasal belgeler arasında yaşanan bu uyumsuzluğun giderilmesi için denetim rehberinin her yıl güncellenmesi sağlanmalı ve ilgili yasal belgelere bağlantı adresi oluşturulmalıdır. Böylece takip etmek kolaylaşacaktır. Aypay (2010) çalışmasında Maarif Müfettişlerinin yaptıkları denetimlerin başarı ile gerçekleşmesi için internetin aktif kullanılması gerektiği üzerinde durulmuştur. Yasal belgelerde yapılan güncellemeler Maarif Müfettişlerine dijital ortamdan ya da kısa mesaj yoluyla ulaştırılabilir. Böylece takip etmeleri kolaylaştırılır.

Bu çalışma Halk Eğitim Merkezleri Rehberlik ve Denetim Rehberi dokümanı içerik analizi yönünden incelenmiştir. Araştırmacılar benzer bir araştırmayı Halk Eğitim Merkezlerinde görev yapan yöneticilere, öğretmenlere ya da maarif müfettişlerine anket yoluyla yapılabilir, onların görüşleri alınabilir. Böylece rehberdeki denetimin uygulanma aşaması değerlendirilip rehbere katkı sağlanabilir. Türkiye'de mevcut denetim modeli, gereksinim odaklı değil, standart değerlendirme odaklıdır (Aydın, 2009). Performansı yeterli olsun ya da olmasın, tüm kurum ve çalışanlar aynı standart süre ve şekilde değerlendirilmektedir. Denetçiler hem ceza veren hem de rehberlik eden konumunda olmamalıdır. Bu denetçiler için dezavantajdır. Oysa $A B$ ülkelerinde eğitim deneticilerinin görev sorumluluğu eğitim ve yönetimle sınırlıdır. Soruşturma görevini ayrı bir birim yürütmektedir (Özmen ve Yasan, 2007). Denetim sisteminin, bu sistemde yer alan maarif müfettişlerinin saygınlığının artması, eğitim çalışanları nezdinde güven veren bir yapıda olması Teftiş Kurulu Başkanlığınca düzenlenen denetim rehberlerinin eksiksiz olması ile sağlanabilir. Rehberde ağırlıkı olarak hukuki dayanakları kullanılmakta buna karşın alanyazın desteği yer almamaktadır. Alanyazın taraması yapıldığında tutarsızıkların içinde içerik eksikliği, alanyazına atıf yapılmaması ve kavram tutarsızlığı oluştuğu görülmektedir. Denetimden daha fazla verim alınması açısından alanyazın desteği önemlidir. Alanyazın temelli tutarsızlıkları gidermek için denetim rehberinde alanyazına atıf yapılabilir. Rehber güncellemeleri yapılırken üniversitelerde denetim alanında uzman kişilerden görüş istenebilir. Rehber içerisinde bu görüşlere yer verilebilir. Rehberin karşılaştırılması için alanyazında bu konuda yapılmış çalışma bulunmadığından bu konuda ileride yapılacak araştırmaların bu tutarsız bulguların geçerliliğini sınamaya katkıda bulunacağı söylenebilir. 


\section{KAYNAKLAR}

Akçay Güngör, A. (2020). Özel Öğrenci Etüt Eğitim Merkezi Rehberlik ve Denetim Rehberinin Yasal Belgeler ve Alanyazın Temelinde İncelenmesi. e-Uluslararası Eğitim Araştırmaları Dergisi, 11 (3) , 90-109. Retrieved from http://www.e-ijer.com/tr/pub/issue/58698/820632

Akyol, B., Başaran, R. ve Yeşilbaş, Y . (2018). Halk Eğitim Merkezlerine devam eden kursiyerlerin yaşam doyum düzeyleri ve yaşam boyu öğrenme eğilimleri. Mehmet Akif Ersoy Üniversitesi Eğitim Fakültesi Dergisi, 2018(48), 301-324.

Altınışı, S. ve Binbir, Ü. (2015). Son onbeş yılda Türkiye'de eğitim denetimine ilişkin yapılan tezlerin analizi. Prof. Dr. Mustafa AYDIN'a Armağan: eğitim ve toplum yazıları. Editör: Mualla BILGiN AKSU, Hasan ŞiMŞEK (1.Baskı). Ankara: Gazi Kitabevi.

Altunay, E. (2016). Eğitim denetimi. E. Toprakçı (Ed.), Eğitbilim: Pedandragoji içinde. Ankara: Ütopya Yayınevi. Apay, A. (2010). Denetici profiline ilişkin sorunlar. Türk Eğitim Bilimleri Dergisi. 8(3), 593-622

Aydın, i. (2009). Eğitim denetiminde değişim ihtiyacı ve yeni paradigmalar. I. Uluslararası Katılımlı Eğitim Denetimi Kongresi (221-224), Ankara.

Aydın, M. (2000). Çağdaş eğitim denetimi. (Yenilenmiş dördüncü baskı). Ankara: Hatiboğlu Yayınevi.

Başar, H. (2000). Eğitim denetçisi. (Beşinci baskı). Ankara: Pegem Akademi.

Berg, B. L. ve Lune, H. (2015). Sosyal bilimlerde nitel araştırma yöntemleri (H. Aydın, Çev. Ed.). Konya: Eğitim Kitapevi Yayınları.

Beytekin, O. F. ve Tas, Ş. (2017). Ortaokul müdürlerinin öğretimsel denetime ilişkin görüşlerinin incelenmesi. Electronic Turkish Studies, 12(33), 115-128.

Bilir, M. (1998). Çağdaş denetçi rolleri. Illköğretim Müfettişleri Semineri (27 Temmuz- 21 Ağustos 1998) Ders Notları (74-98). Ankara: Ankara Üniversitesi Eğitim Bilimleri Fakültesi Eğitim Araştırma ve Uygulama Merkezi.

Bogdan, R. C. and Biklen, S. K. (2007). Qualitative research for education: An introduction to theories and methods. Boston: Pearson.

Bovens, M. (2007). Analysing and assessing accountability: A conceptual framework. European Law Journal, 13(4), 447-468.

Bowen, G. A. (2009). Document analysis as a qualitative research method. Qualitative Research Journal, 9(2), 27-40.

Bursalığlu, Z. (1982), Okul yönetiminde yeni yapı ve davranış (Altıncı baskı). Ankara: Ankara Üniversitesi Eğitim Fakültesi Yayını.

Canatan, Ü. ve Boz, H. (2019). Hayat boyu öğrenme etkinliklerine katılımın aktif yaşlanmanın desteklenmesindeki rolü. Social sciences, 14(3), 343-363.

Corbetta, P. (2003). Social research: Theory, methods and techniques. Thousand Oaks: Sage

Dinevski, D. and Dinevski, I. V.(2004). The concepts of university lifelong learning provision in Europe. Transition Studies Review, 11(3), 227-235.

Duman, A. (1991). Halk eğitiminde denetim. Ankara Üniversitesi Eğitim Bilimleri Fakültesi Dergisi, 24(1), 3744.

Durnalı, M. ve Limon, I. (2018). Çağdaş Türk Eğitim Denetimi Sistemi (değişimler ve yasal dayanakları). Kastamonu Education Journal,26(2),413-425

Fidan, N. (1986). Okulda örenme ve öğretme. Ankara: Kadıoğlu Matbaası.

Field, J. (2001). Lifelong education. International Journal of Lifelong Education, 20(1-2), 3-15.

Glikman, C. D., Gordon, S. P ve Ross-Gordon, J. M. (2014). Denetim ve öğretimsel liderlik: Geliş̧imsel bir yaklaşım. (M. B. Aksu ve E. Ağaoğlu, Çev. Ed.). Ankara: Anı Yayıncılık.

Grace, A. P. (2000). Canadian and US adult learning (1945-1970) and the cultural politics and place of lifelong learning. International Journal of LifelongEducation, 19(2), 141-158.

Guba, E. G. and Lincoln, Y. S. (1994). Competing paradigms in qualitative research. Handbook of qualitative research, 2(105), 163-194.

Güneş, Y. (1985). Halk eğitim merkezlerinde yapılan denetimin etkinliği. Yayımlanmamış yüksek lisans tezi, Ankara Üniversitesi Sosyal Bilimler Enstitüsü, Ankara.

Kahraman, H. (2020). Öğretmenevleri, Öğretmenevi ve Akşam Sanat Okulları Rehberlik ve Denetim Rehberinin Yasal Metinler ve Alanyazın Temelinde İncelenmesi. e-Uluslararası Eğitim Araştırmaları Dergisi, 11 (3) , 123-138 . Retrieved from http://www.e-ijer.com/tr/pub/issue/58698/836759

Karabacak, S. ve Kaygın, H. (2018). Uluslararası yetişkin becerileri araştırmasına (PIAAC) yönelik halk eğitimi merkezlerinde görev yapan eğitimcilerin görüşleri. Electronic Turkish Studies, 13(11), 745-762.

Karagözoğlu, G. (1972). Türk eğitim düzeninde bakanlık müfettişlerinin rolü. (Araştırma Özeti), Ankara: MEB. Plânlama Araştırma ve Koordinasyon Dairesi. 
Katıtaş, S., Coşkun, B. ve Turpçu, M. (2019). Seçilmiş bazı ülkelerin denetim sistemlerinin karşılaştırılması ve Türk eğitim sistemi için bir model önerisi. Journal of Socialand Humanities Sciences Research, 6(48), 4681-4696.

Krippendorff, K. (2018). Content analysis: An introduction to its methodology. London: Sage publications. Lincoln, Y. S. and Guba, E. G. (1985). Naturalistic Inquiry. Beverly Hills, CA: Sage

MEB. (2007a). Millî eğitim bakanlığı iç denetim yönergesi. http://mevzuat.meb.gov.tr/dosyalar/1680.pdf. Erişim tarihi: 30.04.2020.

MEB. (2007b). Avrupa Birliği ülkelerinde eğitim denetimi. https://tkb.meb.gov.tr/yayinlar/AB\%20egitim.pdf Erişim tarihi: 27.01.2021.

MEB. (2018). Millî Eğitim Bakanlığı hayat boyu öğrenme kurumları yönetmeliği. http://hbogm.meb.gov.tr/www/milli-egitim-bakanligi-hayat-boyu-ogrenme-kurumlari-yonetmeligiyayimlandi/icerik/789. Erişim tarihi: 30.04.2020.

Merriam, S. B. and Grenier, R. S. (2019). Qualitative research in practice: Examples for discussion and analysis. San Francisco, CA: Jossey-Bass Publishers.

Meşeci, F. (2007). İngiltere'de ilköğretim performans değerlendirme sistemi ve Türkiye için öneriler. Değerler Eğitimi Dergisi, 5(14), 79-105.

Miles, M. B. and Huberman, A. M. (1994). Qualitative data analysis: An expanded sourcebook. New York: Sage Publications, Inc.

Neuman, W. L. (2008). Toplumsal araştırma yöntemleri: Nicel ve nitel yaklaşımlar (S. Özge, Çev.). İstanbul: Yayın Odası.

OECD (2019). Education at a glance 2019. Erişim: https://www.oecd-ilibrary.org/education/education-at-aglance-2019_f8d7880d-en.

Okçabol, R. (2006). Halk eğitimi (Yetişkin eğitimi) (3. baskı). İstanbul: Ütopya Yayınevi.

Özacun, O. (2001). CHP Halkevleri yayınları bibliyografyası. İstanbul: Kitap Matbaacılık.

Ölmez Ceylan, Ö, Algam, E. (2020). İl/ilçe Milli Eğitim Müdürlükleri Denetim Rehberinin Yasal Belgeler ve Alanyazın Temelinde İncelenmesi. e-Uluslararası Eğitim Araştırmaları Dergisi, 11 (3) , 179-198 . Retrieved from http://www.e-ijer.com/tr/pub/issue/58698/831894

Özdemir, N, Altuntaş, F. (2020). Denetimde Standartlaşma Çabaları: Motorlu Taşıt Sürücüleri Kursu Denetim Rehberi Örneği. e-Uluslararası Eğitim Araştırmaları Dergisi, 11 (3) , 79-89. Retrieved from http://www.e-ijer.com/tr/pub/issue/58698/807767

Özdemir, N. (2020). How to improve teachers' instructional practices: the role of professional learning activities, classroom observation and leadership content knowledge in Turkey. Journal of Educational Administration, 58(6), 585-603.

Özmen, F. ve Yasan, T. (2007). Türk eğitim sisteminde denetim ve Avrupa Birliği ülkeleri ile karşılaştırılması. Fırat Üniversitesi Doğu Araştırmaları Dergisi, 6(1), 204-210.

Sabancı, A. ve Rodoplu, D. (2013). Halk eğitim merkezlerinin denetiminde karşılaşılan sorunlar. EInternational Journal of Educational Research, 4(2), 61-77.

Schleicher, A. (2007). How the world's best-performing school systems come out on top. Paris: OECD

Sullivan, S. and Glanz, J. (2000). Supervision that improves teaching strategies and techniques. California, USA: Corwin Pres.

Taymaz, H. (2005). Eğitim sisteminde teftiş, kavramlar, ilkeler, yöntemler (6. Baskı). Ankara: Pegem Akademi. TKB.(2020).Teftiş Kurulu başkanlığı yayınlarıhttp://tkb.meb.gov.tr/www/yayinlarimiz/icerik/13. Erişim tarihi: 30.04.2020.

Toprakçı, E. (2008). Sınıfa Dayalı Yönetim, Pegem Yayınları, Ankara

Toprakçı, E. (2013). Sınıf Yönetimi. Ankara: Pegem Akademi.

Toprakçı, E. ve Akçay, A. (2016). Türkiye'de kamu yararına çalışan derneklerin eğitim faaliyetlerinin yönetimi ve denetimi (Yasal belgeleri temelinde nitel bir analiz). Cumhuriyet Uluslararası Eğitim Dergisi, 5(1), 29-52.

Toprakçı, E. ve Arslan, M. (2016). Yönetim süreci bağlamında sendikalardaki eğitsel faaliyetlerin yönetimi (yasal belgeler temelinde nitel bir analiz). Çağdaş Yönetim Bilimleri Dergisi, 2(2),1-13

Toprakçı, E., Çakırer, I., Bilbay, A., Bagcivan, E. ve Bayraktutan, I. (2010). Kuram ve uygulamada eğitim denetmenleri meslek etiği. Educational Policy Analysis and Strategic Research, 5(1),14-23

Toprakçı, E. ve Kadı, A. (2014) .Türkiye'deki bakanlıkların eğitim yönetimi ve denetimi alanındaki faaliyetlerinin yasal belgeler eşliğinde analizi. Celal Bayar Üniversitesi Sosyal Bilimler Dergisi, 12(4), 1-18

Toprakçı, E, Bakır, D. (2020). Yabancı, Azınlık ve Milletlerarası Okullar Denetim Rehberinin Yasal Belgeler ve Alanyazın Temelinde İncelenmesi. e-Uluslararası Eğitim Araştırmaları Dergisi, 11 (3) , 16-35. Retrieved from http://www.e-ijer.com/tr/pub/issue/58698/800326 
Toprakçı, E, Özerten, K. (2020). Özel Öğrenci Yurtları Rehberlik ve Denetim Rehberinin Yasal Belgeler ve Alanyazın Temelinde İncelenmesi. e-Uluslararası Eğitim Araştırmaları Dergisi, 11 (3) , 199-216. Retrieved from http://www.e-ijer.com/tr/pub/issue/58698/817509

Tonbul, Y, Ata Çiğdem, F. (2020). Bilsem Denetim Rehberinin Yasal Belgeler ve Alanyazın Temelinde İncelenmesi. e-Uluslararası Eğitim Araştırmaları Dergisi, 11 (3) , 36-62. Retrieved from http://www.eijer.com/tr/pub/issue/58698/804118

Tonbul, Y, Ödemiş Keleş, N. (2020). Mesleki Eğitim Merkezleri Rehberlik ve Denetim Rehberi' nin Yasal Belgeler ve Alanyazın Temelinde Tutarlılığının İncelenmesi. e-Uluslararası Eğitim Araştırmaları Dergisi, 11 (3) , 139-153. Retrieved from http://www.e-ijer.com/tr/pub/issue/58698/803653

Tosun, H. ve Cebeci, A. U. (2006). 5018 Sayılı kamu mali yönetimi ve kontrol kanunu (Açıklamalı ve Karşılaştırmalı), Ankara: MUK-DER Yayını.

Tutar, H. ve Altınöz, M. (2017). Hesap verebilirlik bağlamında iç denetim ve sorun alanları: Eleştirel bir analiz. Bartın Üniversitesi Iktisadi ve İdari Bilimler Fakültesi Dergisi, 8(15), 225-248.

Ünal A. ve Üzüm S. (2014). Eğitim denetçilerinin yeterlikleri ve yetiştirilmesi. V. Eğitim Yönetimi Formu içinde (s. 82-91). Ankara.

Vezne, R. (2017). Avrupa Birliği'nin yaşam boyu öğrenme politikaları bağlamında İngiltere, Danimarka ve Türkiye'nin yetişkin eğitimi sistemlerinin karşılaştırmalı analizi, Ankara Üniversitesi Eğitim Bilimleri Enstitüsü, Ankara

Werquin, P. (2010). Recognising non-formal and informal learning: Outcomes, policies and practices. Paris: OECD Publishing. http://www.eucen.eu/sites/default/files/OECD_RNFIFL2010_Werquin.pdf. Erişim: 23 Ocak 2021.

Williams, J. H. and Engel, L. C. (2012). How do other countries evaluate teachers? Phi Delta Kappan, 94(4), 53-57

Yayla, D. (2009). Türk yetişkin eğitimi sisteminin değerlendirilmesi. Ankara: MEB Yayınları. http://www.meb.gov.tr/earged/earged/Yetiskin_Egitimi.pdf. Erişim tarihi: 30.04.2020.

Yıldırım, A. ve Şimşek, H. (2013). Nitel araştırma yöntemleri. Ankara: Seçkin Yayınevi.

Yıldız, A., Dindar, H., Derya, Ü., Gökçe, N., Kocakurt, Ö. ve Kıral, A. Ö. (2018). Yetişkin yeterliklerinin uluslararası değerlendirilmesi programı (PIAAC) sonuçları bağlamında Türkiye'de temel eğitim sorunlarını yeniden düşünmek. Ankara Üniversitesi Eğitim Bilimleri Fakültesi Dergisi, 51(2), 209-237. 


\title{
Examination of the Public Education Center Supervisory Guideline on the Basis of Legal Documents and Literature
}

\author{
Assoc. Prof. Nedim Özdemir \\ Ege University - Turkey \\ nedim.ozdemir@ege.edu.tr
}

\author{
Aylin Özkanlı (Graduate) \\ Izmir Provincial Directorate of National \\ Education-Turkey \\ aylinozkanli@gmail.com
}

\author{
Fahri Altuntaş (M.A.) \\ izmir Provincial Directorate of National \\ Education-Turkey \\ faltuntas44@gmail.com
}

\begin{abstract}
The aim of this study is to examine the basic parts of the supervision guide prepared by the Ministry of Education chairmanship of the supervision Committee, which is prepared for Public Education Centers, in terms of legal legislation and audit literature. By this means, it is desired to create a new perspective on the supervision guides which serve as the manual of Education Inspectors. In the study, a qualitative research method was adopted and the document analysis technique was used. During the document scanning for this research, doctoral-level theses and articles themed as an "Audit in Public Education Centres", in the last 10 years on the internet, and legal documents included in the guideline were examined. The data obtained were resolved by using content analysis and presented under two themes: legal documents and literature. In the study, it was found that there are many main documentbased inconsistencies according to the legal documents due to the Lifelong Learning Institutions Regulation published after the publication date of the guide. It has been determined that the parts that are consistent according to the legal documents are the legal bases indirectly related to the Public Education Centers. When the literature is regarded, it has been determined that the published supervision guide is generally consistent and includes information related to educational supervision. Despite this consistency, in the audit guide, along with the four codes namely "Lack of Content", "Nonattribution", "Concept inconsistency" and "Contradiction" which were seen in the expressions that differ from the literature, the deficiencies were identified. Findings have been interpreted with the support of legal bases and literature.
\end{abstract}

Keywords: Supervisory Guideline, Supervision, Public Education Center

DOI: 10.19160/ijer.867017

E-International Journal of Educational Research, Vol: 12, No: 1, 2021, pp.124-140

Received: 02.08.2020 Accepted: 28.03 .2021

\section{Suggested Citation:}

Özdemir, N., Özkanlı, A. \& Altuntaş, F. (2021). Examination of the Public Education Center Supervisory Guideline on the Basis of Legal Documents and Literature, E-International Journal of Educational Research, Vol: 12, No: 1, 2021, pp. 124-140, DOI: 10.19160/ijer.867017 


\section{EXTENDED ABSTRACT}

Problem: Public Education Centers are one of the common educational institutions in Turkey. The professional programs, examinations, documents and consultancy of the Public Education Centers are under the control and control of the Ministry of Education. The efficiency and effectiveness of public education centers will increase, like all other institutions in the Turkish education system, with the audits commissioned by the Directorate of Guidance and Supervision Board within the structure of the Ministry of National Education. Public Education Centers Guidance and Supervisory Guideline has been prepared to guide the inspectors through this supervision process. This guide is expected to guide both inspectors and public education centers without deviating from the original purpose of the supervision. In order to achieve this, the audit guide must be prepared in accordance with legal documents and information, in other words with the literature. The study on the supervision of Public Education Centers in the literature is very few. There are no studies on the Guidance and Supervisory Guideline of Public Education Centers. In this study, the Guidance and Supervisory Guideline of Public Education Centers was examined both in terms of legal documents and in terms of the field, and recommendations were made to practitioners and researchers.

Method: Document examination from qualitative research methods was used in this research. Supervision guides were published by the Ministry of Education, evaluated as a public document and a path was followed in accordance with the stages of the document review method. Public Education Centers Guidance and Supervisory Guideline, one of the 16 Supervisory Guidelines published in 2016, is the document of this study. The data in the document was analyzed by content analysis then codes, categories, subthemes and themes were created according to the relevant legal documents after preliminary examinations. Digitization method was also used in order to give an easy to understand perspective of the transformation of data into findings. Finally, the analysis is supported and interpreted with citations determined during the use of the data, which are appropriate according to themes. The internal validity (reliability) of the data has been provided with expert review and professional approval. For this purpose, researchers who examined the supervision guidelines of different institutions met on a specific day and time each week with live meeting tools over the internet. The researchers analyzed codes and themes, by analyzing the content of the guidelines they examined and investigated similar and different aspects of them. In addition, an academic and an inspector attended these meetings and gave feedback. In addition, the raw data of the research is stored for external reliability (verifiability).

Results: The guide was analyzed in regards of legal documents and literature. Consistency and inconsistency subthemes have been established based on these themes. The Regulation of Common Educational Institutions, which is the basis of the Guidance and Supervisory Guideline of Public Education Centers, was abolished on April 11, 2018, and the publication of the Directive on the implementation of Lifelong Learning Institutions Regulation and Public Education Activities constituted the main document-based discrepancies. The inconsistency in which some legal documents have not been updated or repealed has also been inconsistent with other legal documents. After inspecting the field, it was observed that some expressions were in accordance with the literature, and some expressions contained deficiencies or discrepancies. Finally, none of the statements contained in the guide have been referred to scientific research.

Recommendations: Web links may be provided to link current regulations, guidelines, laws and articles in the constitution to resolve the lack of updates in the legal documents contained in the guide. Updates can be delivered to auditors via digital media or SMS. In-service training programs and guidance tasks to be given to supervisors can be prioritized. Formal training and widespread training separation in the education system can also be done in the appointment of inspectors. This distinction may lead them to follow the changes and learn more about institutions. Researchers may get opinions by organizing surveys to the administrators, teachers or education inspectors so that they can contribute to the development of the guide. Scientific sources can be cited for the expressions contained in the guide. Thus, literature screening of future studies becomes easier. When preparing an audit guide, it is recommended to consult with experts in the field of supervision at universities or from experts in adult education. 